\title{
Physical and biogeochemical controls on light attenuation in a eutrophic, back-barrier estuary
}

\author{
N. K. Ganju ${ }^{1}$, J. L. Miselis ${ }^{2}$, and A. L. Aretxabaleta ${ }^{1}$ \\ ${ }^{1}$ U.S. Geological Survey, Woods Hole, Massachusetts, USA \\ ${ }^{2}$ U.S. Geological Survey, St. Petersburg, Florida, USA \\ Correspondence to: N. K. Ganju (nganju@usgs.gov)
}

Received: 2 July 2014 - Published in Biogeosciences Discuss.: 11 August 2014

Revised: 11 November 2014 - Accepted: 13 November 2014 - Published: 17 December 2014

\begin{abstract}
Light attenuation is a critical parameter governing the ecological function of shallow estuaries. In these systems primary production is often dominated by benthic macroalgae and seagrass; thus light penetration to the bed is of primary importance. We quantified light attenuation in three seagrass meadows in Barnegat Bay, New Jersey, a shallow eutrophic back-barrier estuary; two of the sites were located within designated Ecologically Sensitive Areas (ESAs). We sequentially deployed instrumentation measuring photosynthetically active radiation, chlorophyll $a(\operatorname{chl} a)$ fluorescence, dissolved organic matter fluorescence (fDOM; a proxy for colored dissolved organic matter (CDOM) absorbance), turbidity, pressure, and water velocity at $10 \mathrm{~min}$ intervals over 3 -week periods at each site. At the southernmost site, where sediment availability was highest, light attenuation was highest and dominated by turbidity and to a lesser extent chl $a$ and CDOM. At the central site, chl $a$ dominated followed by turbidity and CDOM, and at the northernmost site turbidity and CDOM contributed equally to light attenuation. At a given site, the temporal variability of light attenuation exceeded the difference in median light attenuation between the three sites. Vessel wakes, anecdotally implicated in increasing sediment resuspension, did not contribute to local resuspension within the seagrass beds, though frequent vessel wakes were observed in the channels. With regards to light attenuation and water clarity, physical and biogeochemical variables appear to outweigh any regulation of boat traffic within the ESAs.
\end{abstract}

\section{Introduction}

Back-barrier estuaries, especially along the Atlantic coast of the United States, are typically shallow systems colonized by benthic primary producers (Ziegler and Benner, 1998; Meyercordt et al., 1999; McGlathery et al., 2001). Prior to urbanization and agricultural influence in the watersheds, many systems were characterized by high densities of seagrass and relatively low light attenuation. Subsequent nutrient loading resulting from industrial and agricultural development has led to a gradual decline in seagrass density as eutrophication created water-column algal blooms and overgrowth of benthic algae (Burkholder et al., 2007). Both of these algal succession processes reduce light penetration to seagrass colonies. Evaluating the resiliency of remaining seagrass colonies requires understanding the relative importance of the mechanisms controlling light attenuation in the water column.

There are generally four major factors that reduce light penetration in the water column: the water itself (a function of depth), non-algal particulate material (i.e., suspended sediment), phytoplankton biomass, and colored dissolved organic matter (CDOM) (Kirk, 1994). Generally proxies are used to estimate these quantities in situ: turbidity, chlorophyll $a$ fluorescence, and fluorescing DOM (fDOM). In estuaries, depth is governed by geomorphology and tidal elevations; therefore, light attenuation caused by water is maximized in the deepest channels at high tide and minimized over shoals at low tide. Suspended-sediment concentrations are typically controlled by supply from external sources or local resuspension from the sediment bed (Schoellhamer, 2002). Supply is a function of tidal advection (or riverine 
input) from a non-local repository, while local resuspension can be instigated by tidal currents or wave action (Ganju et al., 2004). Concentrations of chlorophyll $a$ represent the abundance of phytoplankton in the water column, which is a function of nutrient loading, residence time, advection, grazing by zooplankton, and other factors (Phlips et al., 2002; Howarth and Marino, 2006; Glibert et al., 2007). Estuaries with high nutrient loading and long residence times tend to have the highest chlorophyll $a$ concentrations; locations within the estuary far from the nutrient source may experience elevated concentrations due to tidal advection. CDOM is typically associated with a terrestrial end member, leading to an inverse correlation between salinity and CDOM; concentrations may also be elevated in areas draining marsh plains (Downing et al., 2009) and terrestrial watersheds (Spencer et al., 2013).

Instrument limitations typically preclude high temporal resolution $(\sim 1 \mathrm{~h})$ of these parameters over extended periods (i.e., spring-neap cycle). Light and other optical sensors are prone to rapid biofouling, and it is logistically difficult to occupy multiple stations within an estuary. Several studies have quantified the spatial and temporal variability of light attenuation in estuaries, though the spatial and temporal scales vary widely. Phlips et al. (1995) sampled monthly at 17 stations within Florida Bay for 1 year and described spatial variability in light attenuation due to variability in non-algal turbidity and phytoplankton concentrations. Christian and Sheng (2003) conducted synoptic sampling over a 3-month period in the Indian River Lagoon and found that non-algal particulates dominated light attenuation. Both of these studies used non-autonomous light sensors and laboratory determination of chlorophyll $a$ and suspended sediment, thereby limiting temporal resolution. However, with a combination of high-frequency point observations and modeling, Lawson et al. (2007) investigated the influence of suspended sediment on light attenuation in a coastal lagoon and determined that infrequent point monitoring was inadequate for characterizing light dynamics for benthic flora.

The Barnegat Bay-Little Egg Harbor estuary (BBLEH) is a back-barrier estuary on the New Jersey coast (Fig. 1). BBLEH is connected to the Atlantic Ocean via three inlets and is characterized by extensive shallows and maintained navigation channels. The shallows of BBLEH are colonized by seagrass beds of Zostera marina and Ruppia maritima, depending on salinity conditions, with the salt-tolerant Z. marina mostly in the southern portion of the system (Kennish et al., 2013). The influence of the Toms River (and other freshwater sources) lowers salinity in the northern portion of the system, leading to a shift towards $R$. maritima. Seagrass meadows rely on adequate light conditions to maintain productivity and their presence in estuarine systems; changes in light attenuation, sediment quality, and water quality can threaten the persistence of seagrasses. In BBLEH, eutrophication due to anthropogenic nutrient loading has led to decreased water clarity, increased macroalgal proliferation, and

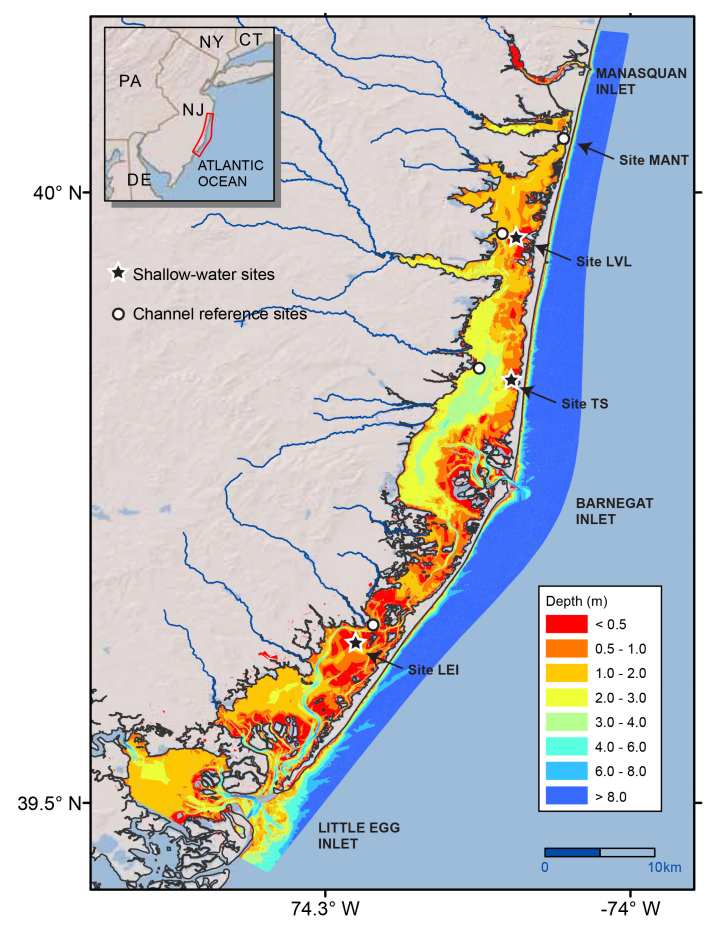

Figure 1. Map of Barnegat Bay, on the New Jersey Atlantic coast. Shoal sites are marked with a star; channel sites are marked with a circle. Estuarine bathymetry is from recent USGS mapping (unpublished).

frequent hypoxia (Kennish et al., 2007, 2011). Concurrently, decreases in areal seagrass meadow coverage have been observed using a combination of remote sensing and field surveys (Lathrop et al., 2006). Within BBLEH, several Ecologically Sensitive Areas (ESAs) have been designated to lessen the effect of both vessel wakes and propeller scars. Many of the ESAs are centered on seagrass meadows, while other well-colonized areas are not within a protected zone. In this study, we aim to quantify the constituents and mechanisms governing light attenuation within seagrass meadows in BBLEH with high temporal resolution at multiple sites. We first detail the observational methods and results of the time-series analysis. We then discuss the spatiotemporal variability of light attenuation, assign relative contributions from different constituents, address the possible role of vessel wakes and wind-waves on sediment resuspension, and discuss the role of sediment availability on spatial differences in light attenuation. Finally, we compare the differences in light and wave climate between ESAs and non-ESAs, and high-vessel-traffic areas vs. low-vessel-traffic areas. 


\section{Methods}

\subsection{Field observations}

We developed a shallow-water platform designed to measure light attenuation and attenuating constituents in the bottom half of a $1 \mathrm{~m}$ water column. The platform consisted of an RBR D|Wave recorder; a pair of WetLabs ECO-PARSB self-wiping photosynthetically active radiation (PAR, 400$700 \mathrm{~nm}$ ) sensors; a YSI EXO multisonde measuring temperature, salinity, turbidity, chlorophyll $a$ fluorescence, fluorescing dissolved organic matter (fDOM, a proxy for CDOM), $\mathrm{pH}$, and depth; and a Nortek Aquadopp-HR $1 \mathrm{MHz}$ current profiler. All instruments except for the upper PAR sensor were mounted at 0.15 meters above bed (mab) on a weighted fiberglass grate approximately $1 \mathrm{~m} \times 0.5 \mathrm{~m}$. The lower PAR sensor was recessed inside a PVC tube protruding from the bottom of the frame, intended to penetrate into the bed. At two sites this required a water-jet apparatus to fluidize the sediment bed and facilitate penetration; turbidity plumes typically subsided within $1 \mathrm{~h}$. The upper PAR sensor was mounted at $0.45 \mathrm{mab}$ to provide an estimate of light attenuation $K_{\mathrm{dPAR}}$ over the PAR spectrum $(400-700 \mathrm{~nm})$, calculated as

$K_{\mathrm{d}}=-\frac{1}{\mathrm{~d} z} \ln \left(\mathrm{PAR}_{\text {lower }} / \mathrm{PAR}_{\text {upper }}\right)$,

where $\mathrm{d} z$ is the distance between the two PAR sensors $(0.3 \mathrm{~m}$ in this case). Light attenuation was calculated only between the hours of 10:30 and 15:30LT, when the angle of the sun relative to the deployment location was closest to $0 \mathrm{de}-$ grees (for the June-September period). A second instrument package consisted of an RBR-D|Wave and a WetLabs ECONTUSB to measure turbidity; this package was deployed in the navigation channel closest to each site. The platform was attached to vertical structures with the sensors approximately $1.5 \mathrm{~m}$ below the water surface at mid-tide. All sensors sampled at intervals between 5 and $10 \mathrm{~min}$, except for the wave recorders which sampled continuously at $6 \mathrm{~Hz}$. Significant wave height and period were calculated using zeroupcrossing statistics over 20 min windows; peak parameters were estimated with a $20 \mathrm{~s}$ window. We identified vessel wakes by comparing the ratio of peak significant wave height over short time windows $(20 \mathrm{~s})$ with the wave height over longer time windows $(20 \mathrm{~min})$; this technique highlights infrequent increases in wave height that are most likely caused by passing vessels. Spectral density estimates for turbidity, chlorophyll $a$, and fDOM were made using the WAFO toolbox (Brodtkorb et al., 2000).

We sequentially occupied three shoal/channel sites during the 25 June-13 September 2013 period (Fig. 1). From south to north, Little Egg Island $\left(\mathrm{LEI}_{\mathrm{sh}}\right)$ and the Route 72 bridge (LEI $\left.{ }_{\text {chan }}\right)$ were occupied from 25 June to 15 July 2013; Tice's Shoal $\left(\mathrm{TS}_{\mathrm{sh}}\right)$ and ICWW marker $28\left(\mathrm{TS}_{\text {chan }}\right)$ were occupied from 16 July to 13 August 2013; and Lavalette $\left(\mathrm{LVL}_{\mathrm{sh}}\right)$ and
ICWW marker $40\left(\mathrm{LVL}_{\text {chan }}\right)$ were occupied from 14 August to 12 September 2013. Depths were $0.9 \mathrm{~m}$ at site $\mathrm{LEI}_{\mathrm{sh}}, 0.8 \mathrm{~m}$ at site $\mathrm{TS}_{\mathrm{sh}}$, and $0.6 \mathrm{~m}$ at site $\mathrm{LVL}_{\mathrm{sh}}$. Depths at channel sites varied but instruments were maintained at a depth of $1.5 \mathrm{~m}$ below surface at mid-tide.

As mentioned above, portions of Barnegat Bay are designated as ESAs, and boaters are encouraged to avoid these areas to minimize damage to seagrass and benthic habitats. Nonetheless, some ESAs experience substantial recreational vessel traffic. Shoal sites were chosen to coincide with one of three archetypes: an ESA with minimal vessel traffic (site $\mathrm{LEI}_{\mathrm{sh}}$ ), an ESA with substantial vessel traffic (site $\mathrm{TS}_{\mathrm{sh}}$ ), and a non-ESA with substantial vessel traffic (site $\mathrm{LVL}_{\mathrm{sh}}$ ). At all three sites, we chose areas with seagrass coverage but deployed the platform on bare patches of the bed within the meadow. Bare patches were typically $10 \mathrm{~m}^{2}$, but surrounded on all sides by vegetation. Kennish et al. (2013) documented seasonal and spatial characteristics of seagrass meadows in Barnegat Bay. We averaged values from the June to September time period, and summed biomass and areal coverage of all species. Northern locations are dominated by Ruppia with total dry biomass of $9 \mathrm{~g} \mathrm{~m}^{-2}$ and $24 \%$ areal coverage, central locations are dominated by Zostera with total dry biomass of $14 \mathrm{~g} \mathrm{~m}^{-2}$ and $32 \%$ areal coverage, and southern locations are entirely Zostera with total dry biomass of $10 \mathrm{~g} \mathrm{~m}^{-2}$ and $26 \%$ areal coverage.

\subsection{Estimation of light attenuation contributions}

Preisendorfer (1976) linked $K_{\mathrm{dPAR}}$ with the inherent optical properties (IOPs) including absorption $(a)$, scattering $(b)$, and/or backscattering $\left(b_{\mathrm{b}}\right)$ coefficients. As measuring scattering accurately remains operationally difficult, Lee et al. (2005) introduced a semi-analytical formulation based only on absorption and backscattering. Gallegos et al. (2011) adopted this approach and adapted it for spectral irradiance to take the form:

$$
K_{\mathrm{d}}(\lambda)=\left(1+0.005 \theta_{0}\right) a(\lambda)+4.18\left(1-0.52 e^{-10.8 a(\lambda)}\right) b_{\mathrm{b}}(\lambda),
$$

where $\theta_{0}$ is the solar incidence angle in degrees, and $K_{\mathrm{d}}(\lambda)$, $a(\lambda)$, and $b_{\mathrm{b}}(\lambda)$ are the spectral attenuation, absorption, and backscattering at frequency $\lambda$ (over the PAR spectrum, 400 $700 \mathrm{~nm})$.

In this study, we use the Gallegos et al. (2011) formulation that computes the quantities needed to form spectral attenuation in terms of suspended and dissolved constituents including the effects of water, CDOM, phytoplankton, and non-algal particulates (NAP, e.g., detritus, minerals, bacteria). We include absorption by four components: (1) absorption by water was assumed to follow the spectral characteristics of pure water; (2) CDOM absorption was taken proportional to fDOM concentration, with a negative spectral slope (Bricaud et al., 1981) set to $s_{\mathrm{g}}=0.0177 \mathrm{~nm}^{-1}$ (within the range of values measured by Gallegos et al., 2011); (3) phytoplankton absorption was proportional to chlorophyll $a$ 


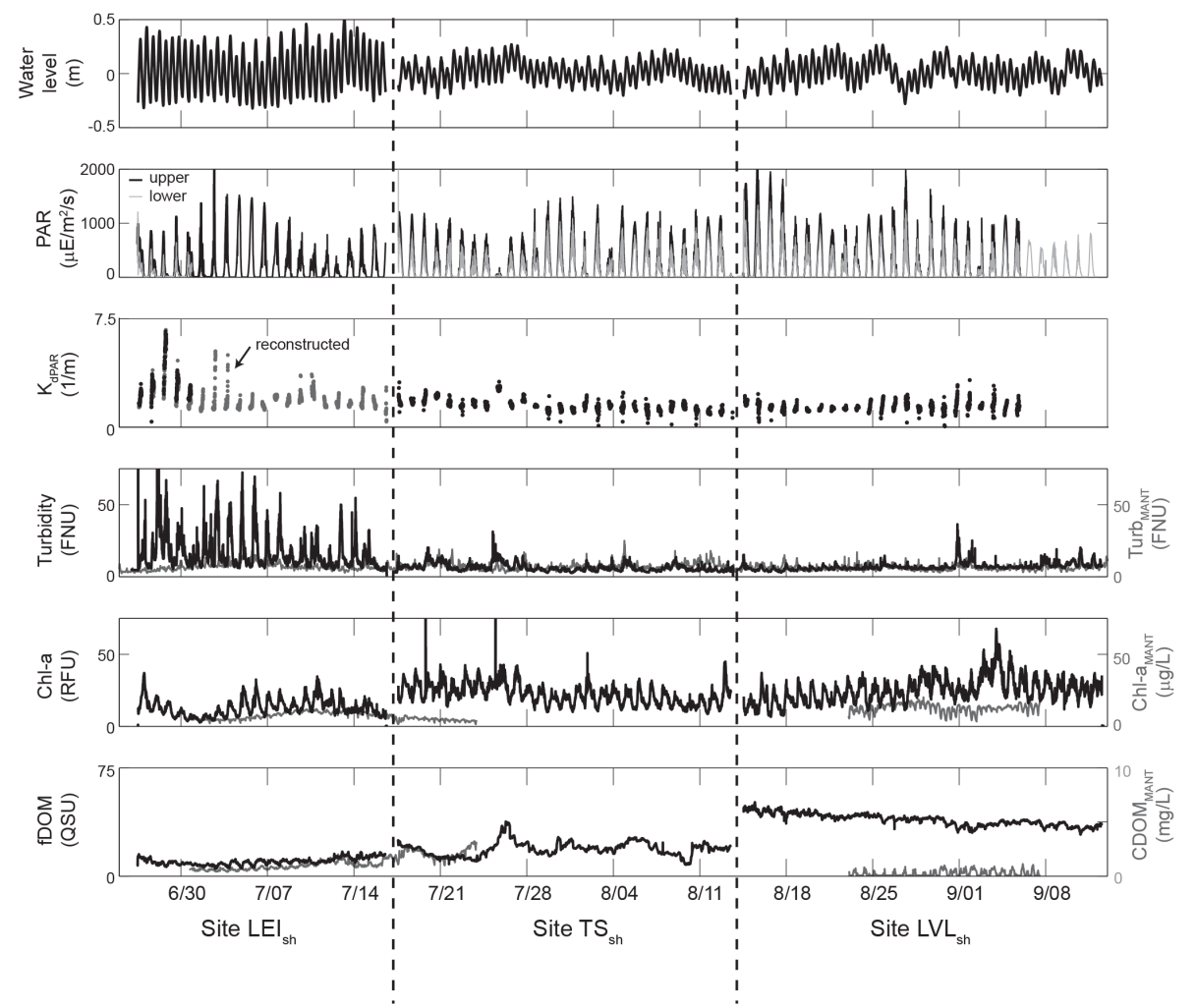

Figure 2. Time series of water level, photosynthetically active radiation (PAR), light attenuation over the PAR spectrum $\left(K_{\mathrm{dPAR}}\right)$, turbidity, chlorophyll $a$ fluorescence ( $\mathrm{chl} a$ ), and fluorescing dissolved organic matter (fDOM) for each site, starting from the south on the left. The grey trace in bottom three panels are reference values from site Mantoloking.
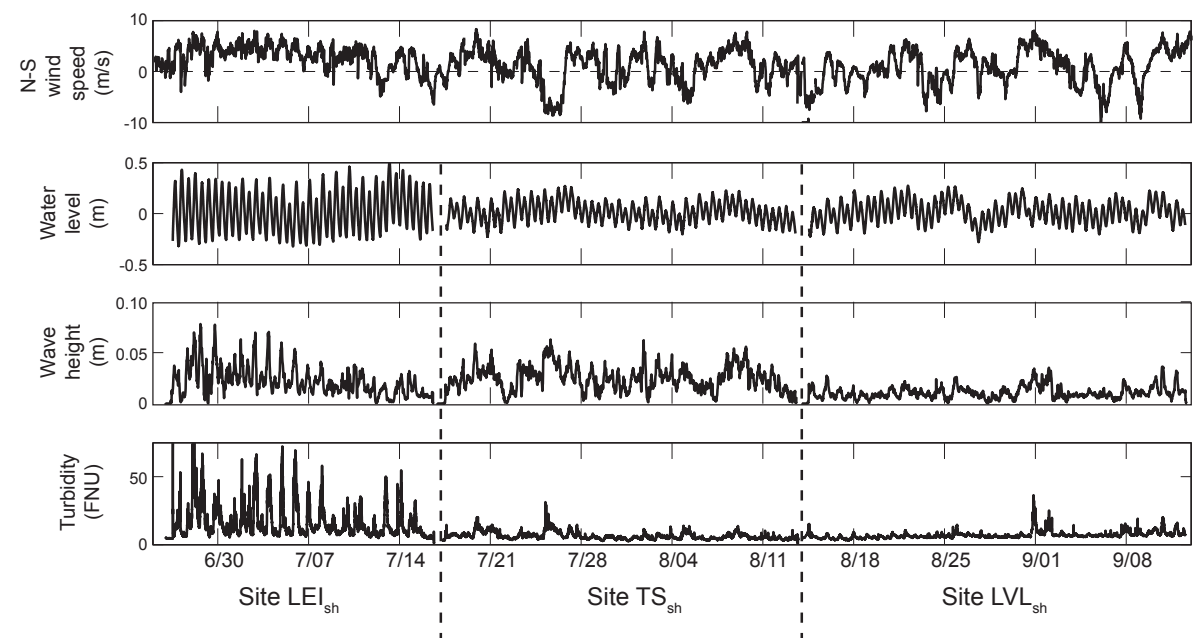

Figure 3. Time series of north-south winds (positive winds from the south), water level, significant wave height at shoal sites, and turbidity for each site, starting from the south on the left.

concentration and with the spectrum shape normalized by the absorption peak at $675 \mathrm{~nm}$ (initial value for peak absorption was taken as $a_{\varphi, 675}=0.0235 \mathrm{~m}^{2}(\mathrm{mg} \operatorname{chl} a)^{-1}$, within the range provided by Bricaud et al., 1995); and (4) non-algal absorption was taken as proportional to the total suspended solids (TSS) concentration with a spectral shape (Bowers and Binding, 2006) that included a baseline of $c_{\mathrm{x} 1}=0.0024 \mathrm{~m}^{2} \mathrm{~g}^{-1}$ (Biber et al., 2008), an absorption cross-section of $c_{\mathrm{x} 2}=0.04 \mathrm{~m}^{2} \mathrm{~g}^{-1}$ (Bowers and Binding, 2006), and a spectral slope of $s_{\mathrm{X}}=0.009$ (Boss et al., 


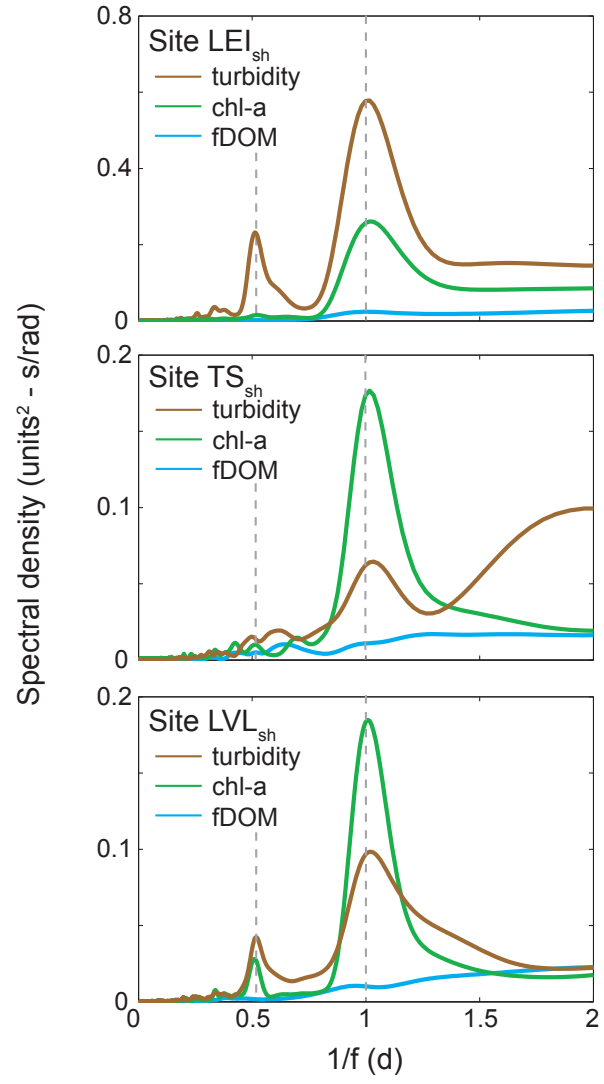

Figure 4. Spectral density of turbidity, chlorophyll $a$, and fDOM time series from three shoal sites. Dashed lines correspond to $M_{2}$ tidal period $(0.5175 \mathrm{~d})$ and the diurnal period $(1 \mathrm{~d})$. Note the difference in $y$ axis scaling at $\mathrm{LEI}_{\mathrm{sh}}$ in comparison to the other two sites.

2001). The backscattering ratio of water was set at 0.5 , while CDOM is considered non-scattering (Mobley and Stramski, 1997), and the particulate effective backscattering ratio was initially set at 0.015 . The composition of NAP in most environments is largely unknown and rapidly changing, resulting in a large variability in the relationship between TSS, absorption, and backscattering. While Gallegos et al. (2011) introduced a range of values depending on the different components of the NAP pool, we chose a constant set of parameters that represented averaged conditions; ultimately the relationship between fDOM and CDOM absorbance appeared to be variable (see below). These parameters were varied to obtain the best agreement between observations and the model.

\subsection{Sediment sampling methods}

Bed sediment samples were collected from the estuarine floor using the mini-SEABOSS system (Valentine et al., 2000), which uses a modified Van Veen sediment grab to collect $0.1 \mathrm{~m}^{2}$ undisturbed seafloor sample. Samples in water less than $1 \mathrm{~m}$ depth (adjacent to the deployment sites) were collected with a hand-held shovel. The upper $2 \mathrm{~cm}$ of the recov- ered sediment was sampled with a scoop and bagged for textural analysis. Approximately $50 \mathrm{~g}$ of wet sample were wet sieved through a $0.062 \mathrm{~mm}$ sieve to separate the coarse and fine fractions. Coarse fractions (sand and gravel) were ovendried, weighed and dry-sieved. Fine fractions (silt and clay) were analyzed using a Coulter Counter Multisizer 3. The combination of both techniques allows for the weight percentages of grain sizes from -5 to 11 phi ( 32 to $<0.001 \mathrm{~mm}$ ) to be determined. The sediment classification and frequency percentages were calculated using GSSTAT software (Poppe et al., 2004), which is based on the methods of Folk (1974) and Collias et al. (1963). Most sampling locations were optimized to groundtruth boat-based acoustic backscatter data rather than to characterize the sites at which light attenuation was measured, and were therefore depth-limited. At sites $\mathrm{LVL}_{\mathrm{sh}}$ and $\mathrm{TS}_{\mathrm{sh}}$, there were several samples within $2 \mathrm{~km}$ of the instrumentation, and a single sample adjacent to each deployment site. At site $\mathrm{LEH}_{\text {sh }}$, other than the deploymentadjacent sample, the closest sediment samples were approximately $5 \mathrm{~km}$ away.

\section{Results}

\subsection{Temporal variability of light attenuation, constituents, and physical forcing}

We discuss the characteristics of the time series at all shoal sites from south to north, beginning with site $\mathrm{LEI}_{\mathrm{sh}}$. Maximum tidal range was about $0.75 \mathrm{~m}$ during spring tides (Fig. 2), though water velocity rarely exceeded $0.20 \mathrm{~m} \mathrm{~s}^{-1}$. PAR was successfully measured at the upper sensor, but the lower sensor unexpectedly failed after $5 \mathrm{~d}$, which precludes the direct measurement of $K_{\mathrm{dPAR}}$ over the entire record. We used Eq. (2) to reconstruct $K_{\mathrm{dPAR}}$ for the remainder of the time period; details of the application of Eq. (2) are given at the end of this section. $K_{\mathrm{dPAR}}$ exceeded $7 \mathrm{~m}^{-1}$ during periods with high turbidity. Turbidity exceeded $50 \mathrm{FNU}$ on several days, due to $M_{2}$ periodic $(12.42 \mathrm{~h}$ ) tidal advection and diurnal wind-wave resuspension (Figs. 2, 3, 4). The chl $a$ demonstrated a diurnal signal (Figs. 2, 4), with troughs during peak daylight (and peaks during lowest light); this is a characteristic signature of non-photochemical quenching (NPQ) whereby chlorophyll fluorescence is reduced at high levels of irradiance (Fig. 5; Maxwell and Johnson, 2000; Lawrenz and Richardson, 2011). Given the long residence time in Barnegat Bay (Defne and Ganju, 2014), it is most likely that NPQ is responsible for these changes rather than tidal advection or daily changes in phytoplankton concentration. The concentration of fDOM was relatively low and constant (Fig. 2) showing a stable relationship with salinity (Fig. 6). Prior work has demonstrated the interference of turbidity with fDOM measurement (Downing et al., 2012); we found low correlation $\left(r^{2}=0.08\right)$ between fDOM and turbidity at this site. Significant wave height approached $0.1 \mathrm{~m}$, peaking 


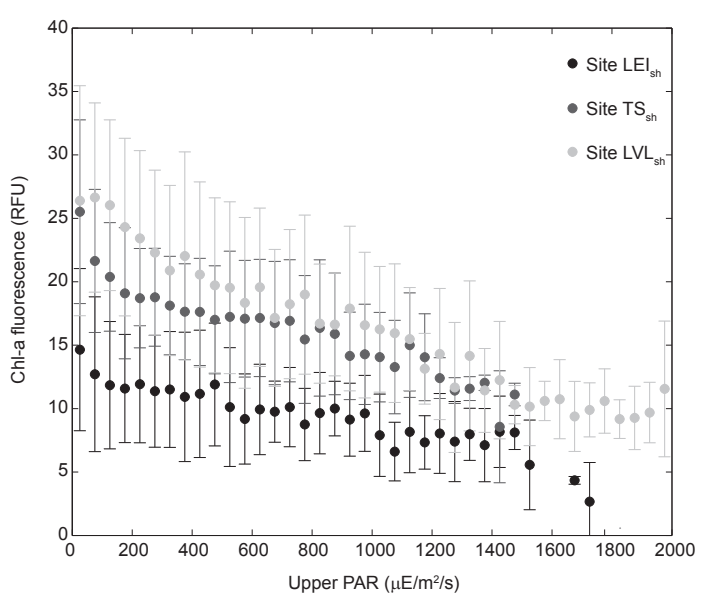

Figure 5. Relationship between binned near-surface irradiance in the PAR spectrum (400-700 nm) and measured chlorophyll $a$ fluorescence. Bounds are one standard deviation of measured fluorescence within each bin. Fluorescence decreases with irradiance at all shoal sites, indicating substantial non-photochemical quenching (NPQ) of fluorescence.

daily during periods of winds from the south (Fig. 3); peak wave height was $0.14 \mathrm{~m}$. This led to a concurrent increase in turbidity during wave events. Wave period ranged from 1.4 to $2.4 \mathrm{~s}$; peak wave periods over $4 \mathrm{~s}$ were observed and attributed to vessel passage due to their anomalous nature (not shown). At the channel site, wave heights were almost 3 times greater (not shown) but out of phase with wind speed. Wave heights in the channel peaked during times with ostensibly more vessel traffic (weekends, early afternoon). We explore the wave characteristics and their relationship to vessel passage at this site further in the Discussion section.

At site $\mathrm{TS}_{\mathrm{sh}}$, maximum tidal range was less than $0.40 \mathrm{~m}$, and water velocity was less than $0.20 \mathrm{~m} \mathrm{~s}^{-1}$ with substantial subtidal variability (Fig. 2). The reduction in tidal range and larger influence of subtidal processes on hydrodynamics in northern Barnegat Bay corroborates prior studies (Chant, 2001; Defne and Ganju, 2014). PAR was successfully measured at both sensors during the entirety of the deployment. $K_{\text {dPAR }}$ peaked over $3 \mathrm{~m}^{-1}$ during a frontal passage on 25 July 2013; strong winds from the north led to a wind-wave sediment resuspension event, and increased river runoff from the Toms River decreased salinity and raised fDOM levels. Apart from the duration of this event, turbidity was less than 20 FNU. Again, chl $a$ demonstrated a diurnal signal (Fig. 4), with troughs during peak daylight (and peaks during lowest light); non-photochemical quenching was again suspected (Fig. 5). The concentration of fDOM was higher than site LEI $_{\text {sh }}$, with a peak during the event of 25 July 2013 (Fig. 2); the relationship with salinity strayed slightly from the relationship at site $\mathrm{LEI}_{\mathrm{sh}}$, suggesting a different source of fDOM (Fig. 6). Significant wave height was less than $0.1 \mathrm{~m}$, peaking during periods of strongest winds (Fig. 3); peak wave height

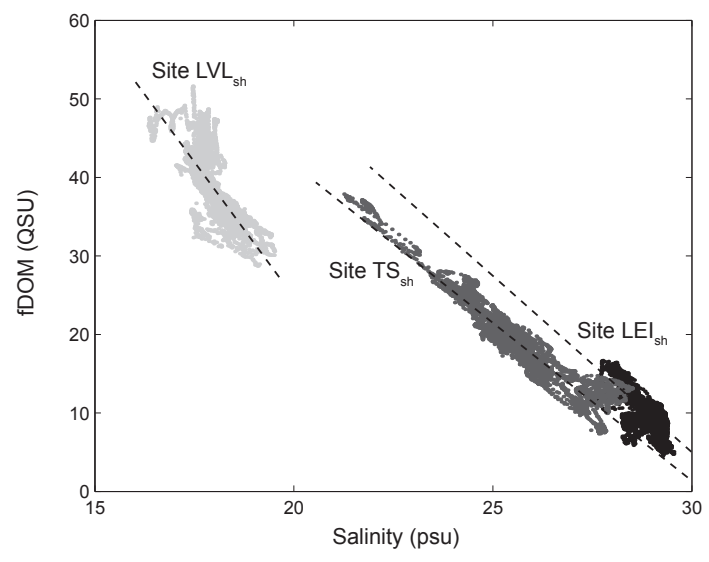

Figure 6. Relationship between salinity and fDOM at three shoal sites, with linear regressions for each population. The three sites appear distinct, suggesting variability in the nature of the fDOM source.

was $0.17 \mathrm{~m}$. Wave period ranged from 1.4 to $3.5 \mathrm{~s}$; peak wave periods over $5 \mathrm{~s}$ were observed regularly (not shown). At the channel site, wave heights were over $0.3 \mathrm{~m}$ (not shown).

The northernmost site $\mathrm{LVL}_{\mathrm{sh}}$ had a tidal range of less than $0.40 \mathrm{~m}$, with velocities exceeding $0.3 \mathrm{~m} \mathrm{~s}^{-1}$ during meteorological events (Fig. 2). PAR was successfully measured at both sensors during all but the last week of the deployment. $K_{\mathrm{dPAR}}$ peaked at over $3.0 \mathrm{~m}^{-1}$ during another frontal passage on 1 September 2013; strong winds from the south led to a wind-wave sediment resuspension event with turbidity exceeding $20 \mathrm{FNU}$. Apart from the duration of this event, turbidity was less than 20 FNU. Non-photochemical quenching was again observed in the chl $a$ time series (Fig. 5). The concentration of fDOM was higher than site $\mathrm{TS}_{\mathrm{sh}}$, but relatively constant (Fig. 2). The relationship with salinity was markedly different than the other sites, suggesting yet another source of fDOM (Fig. 6). Significant wave height was less than $0.05 \mathrm{~m}$, peaking during the frontal passage of 1 September 2013 (Fig. 3); peak wave height was $0.07 \mathrm{~m}$. Wave period ranged from 1.0 to $4.0 \mathrm{~s}$; peak wave periods over $6 \mathrm{~s}$ were observed regularly (not shown). At the channel site, wave heights were over $0.1 \mathrm{~m}$ (not shown). We discuss the diminished sediment resuspension response to wave forcing at sites $\mathrm{LVL}_{\mathrm{sh}}$ and $\mathrm{TS}_{\mathrm{sh}}$ in the following section.

\subsection{Spatial variability of median measurements}

The median values of physical forcings, light attenuation, and constituents demonstrate a large spatial gradient of external forcings and water quality in Barnegat Bay (Table 1). While tidal velocity was relatively similar over all shoal sites, median wave height was minimized at the northern site $\mathrm{LVL}_{\mathrm{sh}}$, where limited fetch likely contributes to reduced wave heights. The south-to-north salinity gradient is caused by substantially higher river outflow from northern 
Table 1. RMS values of velocity (absolute value), and median values of wave height, salinity, light attenuation $K_{\mathrm{dPAR}}$ ), and attenuating constituents from three sites and reference site Mantoloking. Value in parentheses at Mantoloking covers the same temporal overlap of the study sites.

\begin{tabular}{lrrrr}
\hline & LEI $_{\text {sh }}$ & $\mathrm{TS}_{\text {sh }}$ & LVL $_{\text {sh }}$ & Mantoloking \\
\hline RMS velocity $\left(\mathrm{m} \mathrm{s}^{-1}\right)$ & 0.06 & 0.05 & 0.07 & NA \\
Wave height $(\mathrm{m})$ & 0.02 & 0.02 & 0.01 & NA \\
Salinity (psu) & 28 & 26 & 18 & NA \\
$K_{\text {dPAR }}\left(\mathrm{m}^{-1}\right)$ & $2.7(1.9)^{\mathrm{a}}$ & 1.4 & 1.4 & NA \\
chl $a(\mathrm{RFU})^{\mathrm{b}}$ & 12 & 21 & 24 & $9(8,4,13)$ \\
fDOM $(\mathrm{qsu})^{\mathrm{c}}$ & 10 & 19 & 39 & $0.6(1,2,0.2)$ \\
Turbidity (FNU) & 12 & 6 & 6 & $6(7,7,6)$ \\
\hline
\end{tabular}

${ }^{\text {a }}$ First value is from period with complete PAR data (26-30 June 2013), second value is reconstructed data for entire period (26 June-16 July 2013) using Eq. (2).

${ }^{\mathrm{b}} \mathrm{Chl} a$ values at Mantoloking are reported in $\mu \mathrm{g} \mathrm{\textrm {L } ^ { - 1 }}$.

c fDOM values at Mantoloking are reported as CDOM in $\mathrm{mg} \mathrm{L}^{-1}$.

tributaries such as the Toms and Metedeconk rivers. This transport, coupled with higher nutrient loading in the north (Kennish et al., 2007) likely explains the increased chl $a$ and fDOM in the northern bay. However, light attenuation is maximized in the southern bay at site $\mathrm{LEI}_{\text {sh }}$ due to elevated turbidity. Both fDOM and chl $a$ were minimized at this site, due to reduced freshwater and nutrient loading. Measurements at the continuously occupied site Mantoloking indicate that the sequential nature of our deployments did not complicate interpretation of these patterns: turbidity was relatively constant throughout the summer, while neither fDOM nor chl $a$ increased as summer progressed, though there was an increase spatially as sites were occupied from south to north.

\subsection{Sediment composition}

Samples were collected at 9 locations near sites $\mathrm{LVL}_{\mathrm{sh}}$ and $\mathrm{TS}_{\mathrm{sh}}$, and 12 locations southwest of $\mathrm{LEI}_{\mathrm{sh}}$, as well as one sample adjacent to each deployment site (Fig. 7). Grain-size analyses revealed a coarsening of sediment from south to north (Table 2). Samples collected adjacent to site $\mathrm{LEI}_{\text {sh }}$ had over double the clay percentage of the other sites and less sand. Median particle diameter $D_{50}$ at site $\mathrm{LEI}_{\text {sh }}$ was in the medium silt range, while $D_{50}$ was in the very fine sand and coarse silt range at sites $\mathrm{TS}_{\mathrm{sh}}$ and $\mathrm{LVL}_{\mathrm{sh}}$, respectively. Sites $\mathrm{TS}_{\mathrm{sh}}$ and $\mathrm{LVL}_{\mathrm{sh}}$ both reside on the landward side of the barrier island, which has historically been subjected to overwash events (Donnelly et al., 2001). Overwash processes deposit sand on the landward side of the barrier island into the estuary leading to coarser deposits in these areas (Oertel, 1985). Conversely, site $\mathrm{LEI}_{\mathrm{sh}}$ is on the landward side of the estuary adjacent to the mainland, which is fringed by extensive marsh. These marshes represent a local source of fine sediment that can be released during marsh collapse under wave forcing (Mariotti and Fagherazzi, 2013; Ganju et al., 2013).
Table 2. Sediment grain-size results for combined samples collected near deployment sites with mini-SEABOSS grab sampler.

\begin{tabular}{lrrr}
\hline Parameter & LEI & TS & LVL \\
\hline$\%$ sand & 43 & 62 & 55 \\
$\%$ silt & 39 & 31 & 38 \\
\% clay & 18 & 7 & 7 \\
$D_{50}(\mathrm{~mm})$ & 0.028 & 0.084 & 0.056 \\
\hline
\end{tabular}

\section{Discussion}

\subsection{Relative contributions to light attenuation}

The application of Eq. (2) allows for estimating the relative contributions of turbidity, chl $a$, and CDOM to light attenuation at each site (Table 3 ). Turbidity dominated the light attenuation at site $\mathrm{LEI}_{\mathrm{sh}}$, while chl $a$ was dominant at site $\mathrm{TS}_{\mathrm{sh}}$; CDOM was important at site $\mathrm{LVL}_{\mathrm{sh}}$ (though secondary to turbidity) due to its proximity to freshwater sources such as the Toms River. These results suggest that physical processes (sediment resuspension and advection) are dominant at sites $\mathrm{LEI}_{\mathrm{sh}}$ and $\mathrm{LVL}_{\mathrm{sh}}$, while water-quality processes (nutrient loading and phytoplankton proliferation) are more important at site $\mathrm{TS}_{\mathrm{sh}}$. This is supported by the residence time calculations of Defne and Ganju (2014) that demonstrate areas between sites $\mathrm{TS}_{\mathrm{sh}}$ and $\mathrm{LVL}_{\mathrm{sh}}$ are poorly flushed, leading to less dilution of estuarine waters by seawater and enhancing phytoplankton proliferation.

Before implementing the light model, we removed the effect of non-photochemical quenching (Fig. 4) by eliminating chl $a$ measurements during periods when PAR exceeded $50 \mu \mathrm{E} \mathrm{m}^{-2} \mathrm{~s}^{-1}$ and filling the gaps using linear interpolation. We selected an initial slope of fDOM fluorescence to CDOM absorbance based on measurements from several estuaries (Chen et al., 2008). We then applied the model with the default parameters noted above (Table 4), and compared modeled $K_{\mathrm{dPAR}}$ to the field measurements at each site. We modified three parameters selectively based on correlations between residual error and the different constituents to obtain the highest correlation and lowest error (Fig. 8). Attempts at a standard multiple linear regression model led to spurious results in some cases (e.g., inverse relationship between fDOM and $K_{\mathrm{dPAR}}$ at site $\left.\mathrm{LVL}_{\mathrm{sh}}\right)$. The variability in the fDOM vs. salinity relationship supports the possibility that the source and optical properties of colored organic matter varies spatially in Barnegat Bay; Oestreich et al. (2014) demonstrated large spatial variability in CDOM absorbance potential per unit fluorescence, as a function of source. Spectral slope within Barnegat Bay varied by approximately $15 \%$, resulting in calculated changes to $K_{\mathrm{dPAR}}$ of less than $4 \%$. Additionally, variability in turbidity and organic content of suspended sediment also suggests that particulate backscattering ratio may be spatially variable; suspended-sediment samples demonstrated organic content ranging from $13 \%$ at site LEI 
Table 3. Contributions to light attenuation from three constituents. The effect of water depth is removed from these calculations.

\begin{tabular}{lrrr}
\hline Constituent & LEI $_{\text {sh }}$ & TS $_{\text {sh }}$ & LVL $_{\text {sh }}$ \\
\hline chl $a$ & $17 \%$ & $44 \%$ & $22 \%$ \\
CDOM & $14 \%$ & $21 \%$ & $36 \%$ \\
Turbidity & $69 \%$ & $35 \%$ & $42 \%$ \\
\hline
\end{tabular}

Table 4. Parameters used for light model of Gallegos et al. (2011), Eq. (2): $s_{\mathrm{g}}=$ spectral slope of CDOM; $a_{\varphi, 675}=$ chlorophyll peak absorption; $c_{\mathrm{x} 1}=$ baseline non-algal absorption; $c_{\mathrm{x} 2}=$ non-algal absorption cross-section; $s_{\mathrm{X}}=$ non-algal spectral slope; $b_{\mathrm{b} \text { (water) }}=$

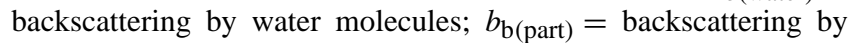
particulates.

\begin{tabular}{lrrr}
\hline Parameter & $\mathrm{LEI}_{\mathrm{sh}}$ & $\mathrm{TS}_{\mathrm{sh}}$ & $\mathrm{LVL}_{\mathrm{sh}}$ \\
\hline$s_{\mathrm{g}}\left(\mathrm{nm}^{-1}\right)^{\mathrm{a}}$ & 0.0177 & 0.0177 & 0.0177 \\
$a_{\varphi, 675}\left(\mathrm{~m}^{2} \mathrm{mg}^{-1}\right)$ & 0.0235 & 0.0235 & 0.0130 \\
$c_{\mathrm{X} 1}\left(\mathrm{~m}^{2} \mathrm{~g}^{-1}\right)^{\mathrm{b}}$ & 0.0024 & 0.0024 & 0.0024 \\
$c_{\mathrm{X} 2}\left(\mathrm{~m}^{2} \mathrm{~g}^{-1}\right)^{\mathrm{c}}$ & 0.04 & 0.04 & 0.04 \\
$s_{\mathrm{X}}\left(\mathrm{nm}^{-1}\right)^{d}$ & 0.009 & 0.009 & 0.009 \\
$b_{\mathrm{b} \text { (water })}$ & 0.5 & 0.5 & 0.5 \\
$b_{\mathrm{b} \text { (part) }}$ & 0.025 & 0.015 & 0.015 \\
\hline
\end{tabular}

${ }^{\mathrm{a}}$ Gallegos et al. (2011); ${ }^{\mathrm{b}}$ Biber et al. (2008); ${ }^{\mathrm{c}}$ Bowers and Binding (2006); ${ }^{d}$ Boss et al. (2001).

to $60 \%$ at site LVL. The backscattering ratio change from 0.015 to 0.025 at $\mathrm{LEI}_{\mathrm{sh}}$ is within the range ( 0.0024 to 0.06 , Loisel et al., 2007 and Snyder et al., 2008) provided by Gallegos et al. (2011). While scattering by organic particles is strongly in the forward direction (smaller value of $b_{\mathrm{b} \text { (part) }}$ ), mineral particles, having larger refraction indices, scatter a greater fraction of light in the backward direction (larger $b_{\mathrm{b} \text { (part) }}$ ). The dependency of backscattering on particle size results in smaller modifications of $b_{\mathrm{b} \text { (part) }}$ than the refraction index differences between organic and mineral particles (Gallegos et al., 2011). Thus a larger backscattering ratio was expected in the areas with higher turbidity (site LEI). Finally, marked variability in phytoplankton community composition suggests that chlorophyll absorbance at specific wavelengths may be variable (Ren, 2013). The chlorophyll-specific absorption coefficients of natural phytoplankton $\left(a_{\varphi, 675}\right)$ exhibit substantial variability (Bricaud et al., 1995) with higher values for oligotrophic waters and smaller coefficients for eutrophic environments, which is consistent with the lower absorption coefficient chosen for $\mathrm{LVL}_{\mathrm{sh}}$ (highest chl $a$ concentration).

At the lower end of the comparison between observed and modeled $K_{\mathrm{dPAR}}$ (i.e., modeled $K_{\mathrm{dPAR}}<1.6$ ), we find reduced sensitivity of the model to changes in observed turbidity, chl $a$, and fDOM. This could be due to changes in either particle characteristics or other effects that would be more obvious at low attenuation, such as interference from surface
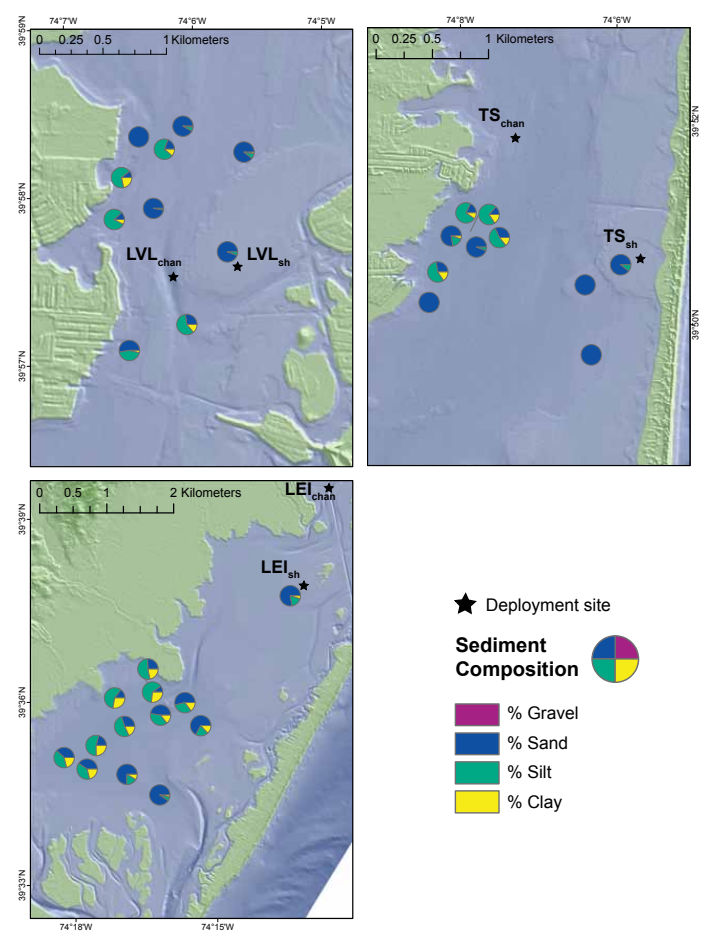

Figure 7. Surficial sediment composition adjacent to deployment sites. A higher abundance of clay-sized sediment is available near site LEI as compared to the other sites.

waves. It is also possible that the model parameterization for the three attenuating substances fails at the low end because the parameters (Table 4) are not static. We also assume that constituent concentrations are uniform between the two PAR sensors; changes in vertical gradients between quiescent and energetic periods could also alter the agreement. We chose to optimize the relationship for high $K_{\mathrm{dPAR}}$, but could have alternatively selected parameters to optimize for agreement at the low end.

\subsection{Temporal and spatial variability in light attenuation}

Many prior studies and current estuarine monitoring protocols utilize infrequent (e.g., daily or weekly) sampling for water quality parameters including light attenuation (or Secchi depth as a proxy). We found that temporal variability in light attenuation at each site was much larger than the difference between the median values at the three sites. At site $\mathrm{LEI}_{\mathrm{sh}}$, maximum $K_{\mathrm{dPAR}}$ was over $7 \mathrm{~m}^{-1}$ during a wind event, which caused increased turbidity; during quiescent periods $K_{\text {dPAR }}$ decreased to $1.2 \mathrm{~m}^{-1}$. At site $\mathrm{TS}_{\mathrm{sh}}$, a storm/runoff event raised $K_{\mathrm{dPAR}}$ to a peak value of $2.8 \mathrm{~m}^{-1}$; the minimum value was $0.8 \mathrm{~m}^{-1}$. Another wind event led to a peak $K_{\mathrm{dPAR}}$ of $2.9 \mathrm{~m}^{-1}$ at site $\mathrm{LVL}_{\mathrm{sh}}$, while the minimum value was under $1.0 \mathrm{~m}^{-1}$. Daily or weekly sampling would not capture this variability, and sampling during a peak or minimum event 


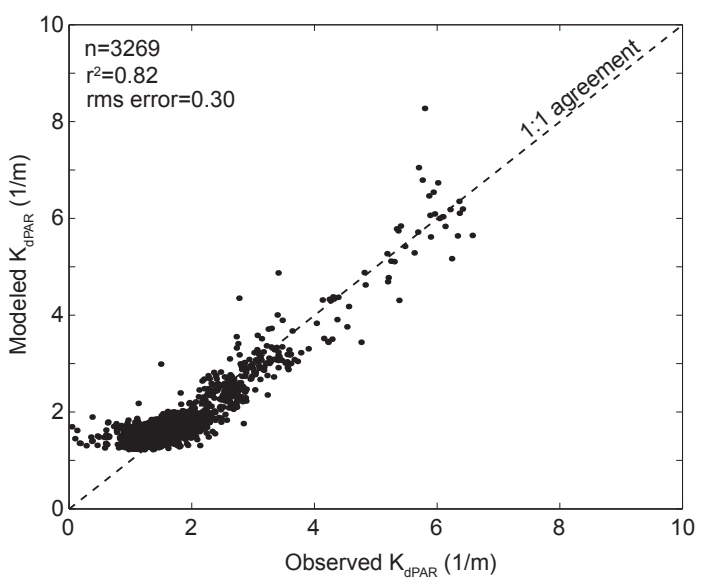

Figure 8. Agreement between observed $K_{\mathrm{dPAR}}$ over the PAR spectrum and the spectral attenuation model of Gallegos et al. (2011).

(more likely, as sampling is biased towards calm conditions) may skew the resulting interpretation of light penetration. We find that daily sampling at a set time (8:00 a.m. local time, in this case) resulted in mean light attenuation errors ranging from $2 \%$ at site TS to $17 \%$ at site LEI. Sites with large temporal variability in constituents, like turbidity, will likely have the largest increases in error as sampling interval is lengthened. While it is cost-prohibitive to monitor light attenuation continuously at multiple sites, spatial and temporal patterns deduced from infrequent measurements should be interpreted with care or supplemented by more complete measurements (e.g., proxy measurements or modeling).

Spatially, the increased light attenuation in the south is mainly forced by turbidity. Regular resuspension and advection events on tidal and diurnal timescales (Figs. 2, 3, 6) increase turbidity and light attenuation at site $\mathrm{LEI}_{\mathrm{sh}}$ throughout the deployment. Moving northward, light attenuation is governed increasingly by biogeochemical components, congruent with the longer residence time and decreased flushing in the northern bay (Defne and Ganju, 2014). The northern bay is also subjected to elevated nutrient loads from the more developed watershed (Kennish et al., 2007). Conversely, the southern portion of the bay is fringed by wetlands, which represent a large source of fine sediment through shoreline erosion (see below). This pattern suggests a south-to-north gradient in light attenuation that is forced by a south-to-north gradient in physical forcing, sediment availability, and nutrient loading.

\subsection{Sediment transport on the shoals: resuspension mechanisms and fine sediment supply}

Sediment sampling confirmed a greater abundance of claysized material in the southern bay, suggesting an increased likelihood of resuspension under wave forcing. We computed wave-current combined bed shear stresses (Madsen, 1994) at the three shoal sites and found varying resuspension re-

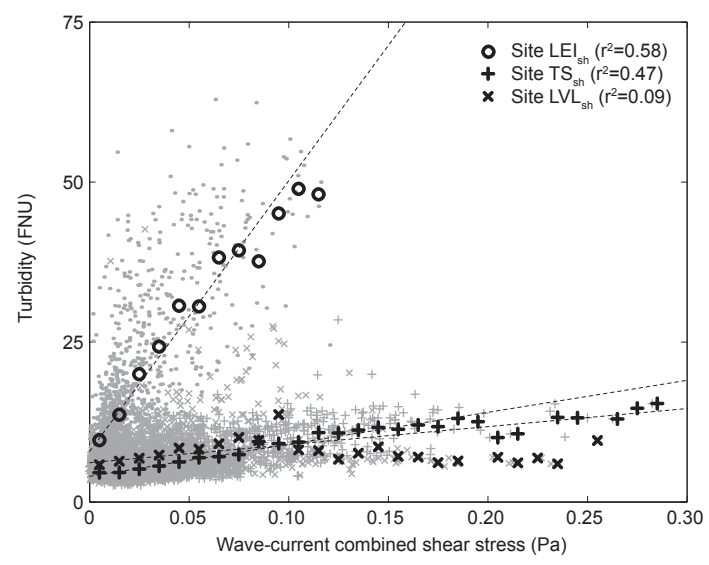

Figure 9. Relationship between wave-current combined shear stress and turbidity at three shoal sites; darker symbols are instantaneous data binned and averaged in $0.01 \mathrm{~Pa}$ intervals. Site $\mathrm{LEI}_{\mathrm{sh}}$ demonstrates enhanced resuspension as compared to other sites under similar stress conditions; surficial sediment distribution indicates a higher abundance of fine material in the southern part of the system.

Table 5. Statistics and correlation of turbidity between channel and shoal at three sites.

\begin{tabular}{lrrrrrr}
\hline Statistic & $\mathrm{LEI}_{\text {sh }}$ & $\mathrm{LEI}_{\text {chan }}$ & $\mathrm{TS}_{\text {sh }}$ & $\mathrm{TS}_{\text {chan }}$ & $\mathrm{LVL}_{\text {sh }}$ & $\mathrm{LVL}_{\text {chan }}$ \\
\hline$r^{2}$ & 0.38 & - & 0.30 & - & 0.24 & - \\
$50 \%(\mathrm{FNU})$ & 12 & 13 & 5.7 & 6.0 & 6.2 & 6.9 \\
$99 \%(\mathrm{FNU})$ & 54 & 47 & 14 & 22 & 18 & 14 \\
\hline
\end{tabular}

sponses to bed stress. At sites $\mathrm{LEI}_{\mathrm{sh}}$ and $\mathrm{TS}_{\mathrm{sh}}$, turbidity responded linearly with stress; but turbidity was nearly 5 times larger at site $\mathrm{LEI}_{\mathrm{sh}}$ for a given stress (Fig. 9). This confirms a larger repository of erodible material at the site, likely due to supply from adjacent wetlands. Samples closest to site $\mathrm{TS}_{\mathrm{sh}}$ indicate that the bed is nearly all sand-sized material, which would only be resuspended at the highest stresses (Fig. 9). At site $\mathrm{LVL}_{\mathrm{sh}}$, the weak correlation and diminished resuspension response suggests a limited pool of erodible material. The secondary spectral density peak at the $M_{2}$ tidal period at $\mathrm{LEI}_{\mathrm{sh}}$ (Fig. 4) raises the possibility that sediment advection from a far-field source may be important, and that local resuspension is not dominant. Waves accounted for $56 \%$ of the calculated shear stress at site $\mathrm{LEI}_{\mathrm{sh}}, 64 \%$ at site $\mathrm{TS}_{\mathrm{sh}}$, and $45 \%$ at site $\mathrm{LVL}_{\mathrm{sh}}$.

Turbidity measurements at all channel/shoal-paired sites show that longitudinal (north-south) variability was larger than lateral (channel-shoal) variability (Table 5). Median and extreme $(99 \%)$ values of turbidity were similar between paired sites; correlation was highest in the south (where forcing was consistent) and lower in the north where episodic events dominated. Estuarine shoals are typically subjected to greater wind-wave resuspension than channels, but the channels are the conduit for subsequent advection of suspended 

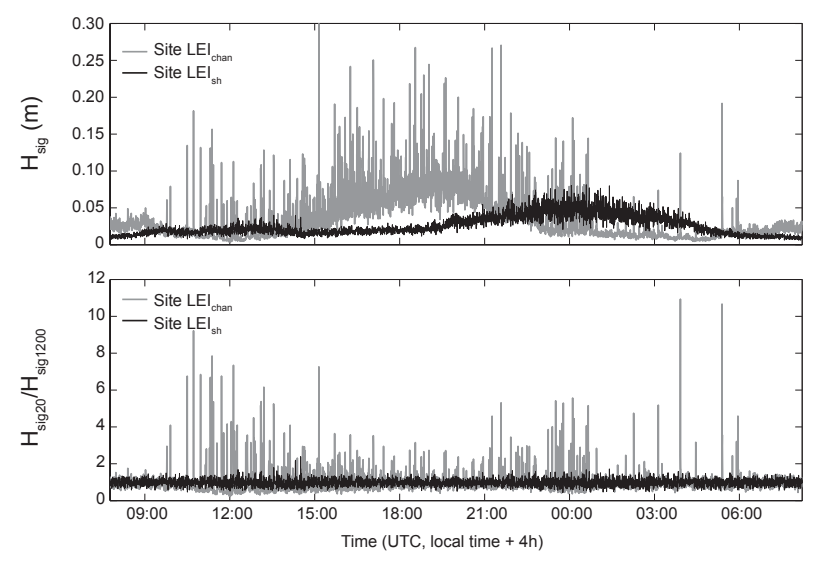

Figure 10. Example of a single day of significant wave height $\left(H_{\text {sig }}\right)$ data from sites $\mathrm{LEI}_{\text {chan }}$ and $\mathrm{LEI}_{\text {sh }}$, and the ratio of $20 \mathrm{~s}$ window significant wave height $\left(H_{\text {sig20 }}\right)$ to $1200 \mathrm{~s}$ window significant wave height $\left(H_{\text {sig1200) }}\right.$. The latter metric is used to identify vessel wakes, which are observed frequently at site $\mathrm{LEI}_{\text {chan }}$, but seldom at site $\mathrm{LEI}_{\text {sh }}$.

sediment. Given the dominance of shoals in Barnegat Bay, it is not surprising that channels adjacent to shoals are influenced by shoal processes. As discussed above however, the longitudinal variability in sediment source and availability explains the large longitudinal gradient in turbidity and light attenuation. From a sampling point-of-view, it appears that dense longitudinal sampling is more critical than lateral sampling, at least for turbidity and suspended-sediment concentration. The role of submerged aquatic vegetation in shoal resuspension processes can be substantial. Seagrass canopies can alter the velocity profile (Lacy and WyllieEcheverria, 2011) and dampen waves (Fonseca and Cahalan, 1992). While we did not quantify the effect of seagrass meadows on these processes, it is possible that differences in vegetative density and areal coverage could modify the response of the seabed to a given resuspension event.

\subsection{Role of vessel wakes in sediment resuspension}

Due to the frequent resuspension and advection events at site $\mathrm{LEI}_{\mathrm{sh}}$ (relative to the northern sites), we focused our analysis of vessel-induced sediment resuspension on this site. At the shoal site, the ratio of $20 \mathrm{~s}$ significant wave height to 20 min significant wave height hovered around 1, indicating almost no local vessel wakes, while the ratio fluctuated widely at the channel site (Fig. 10). Turbidity between the channel and shoal was well-correlated, with similar medians and extreme values (Table 5); however correlation between wave height and wind speed was weak at the channel site $\left(r^{2}=0.03\right)$ but strong at the shoal site $\left(r^{2}=0.44\right)$. Similarly, correlation between turbidity and wave height at the channel site was extremely low $\left(r^{2}<0.01\right)$ while it is high at the shoal site $\left(r^{2}=0.52\right)$. This suggests that local resuspension from wind-waves is responsible for increased turbidity

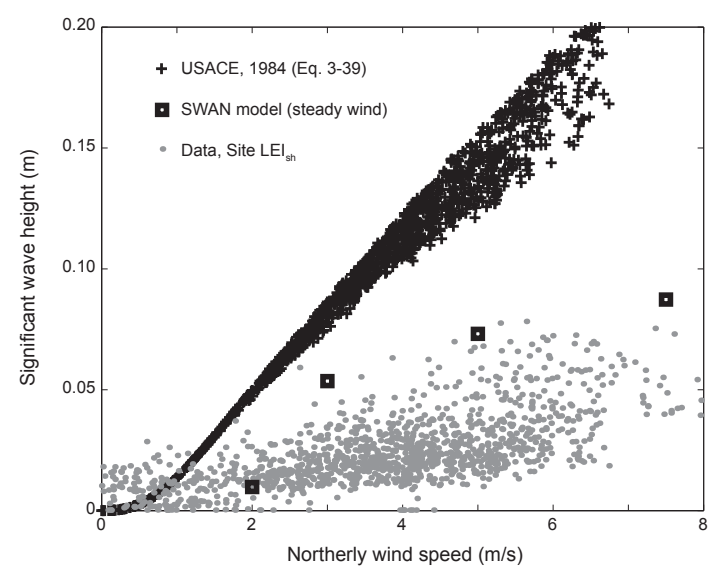

Figure 11. Measured and modeled wave-height response to wind at site $\mathrm{LEI}_{\mathrm{sh}}$; the USACE formulation neglects spatial variation in bathymetry and the SWAN model does not include the influence of tidal currents and assumes a constant, uniform wind field.

at the shoal site, and that advection from shoals is responsible for increases in turbidity at the channel site. It also suggests that the shoal site is representative of a broader area; i.e., diurnal winds over the entire southern bay increase turbidity throughout the area allowing for advection into the channels. Wave heights in the channel tended to peak in the late afternoon (local time) though the peak of wake occurrence varied, while wave heights over the shoal peaked during the period of maximum winds. We also estimated wave heights over the shoals with a fetch-limited, shallow water approximation (USACE, 1984) and with a SWAN (Booij et al., 1999) wave model of Barnegat Bay forced with steady winds in the northerly direction. These simulations show that the observed winds are more than capable of causing the observed waves, without invoking vessel wakes (Fig. 11). However, given the separation between the sites it is likely that vessel wakes in the channel are attenuated rapidly as they encounter the channel-shoal transition. At these locations it is possible that turbidity is locally enhanced, but this is not reflected in either channel or shoal measurements.

\subsection{Influence of regulation, ESA status, and vessel traffic on light attenuation}

Increased population in the Barnegat Bay region has led to concerns about the effect of recreational boating on estuarine ecological function (EPA, 2007). In response to these concerns, Environmentally Sensitive Areas (ESAs) were established to ostensibly protect seagrass-colonized shoals from scarring and sediment resuspension due to vessel traffic (NJDEP, 2012). We occupied three distinct vegetated shoal habitats in Barnegat Bay, each representing a different combination of protection and anthropogenic exposure (Lathrop and Haag, 2011): (1) a protected ESA near an area with lower coastal development and vessel harborage (site $\mathrm{LEI}_{\mathrm{sh}}$ ); (2) a 
protected ESA with relatively high recreational vessel traffic (site $\mathrm{TS}_{\mathrm{sh}}$ ); and (3) an unprotected site with relatively high recreational vessel traffic $\left(\right.$ site $L_{V L}$ sh $)$. Our results show that physical variables (wind-wave resuspension, sediment availability) outweigh both protection and potential vessel traffic in terms of light attenuation over seagrass meadows. Site $\mathrm{LEI}_{\mathrm{sh}}$ is designated for protection, yet light attenuation is maximized at that site due to wind-waves and sediment resuspension. Both of these parameters are outside the sphere of regulation and suggest that a future decrease in light attenuation to seagrass meadows at this site is unlikely (in lieu of a long-term depletion of sediment supply). It should be noted that protection does decrease the likelihood of propeller scarring, something this study does not address. The light attenuation and constituent measurements provide an estimate of what gains can be made through reduction of anthropogenic nutrient loads. Sites $\mathrm{TS}_{\mathrm{sh}}$ and $\mathrm{LVL}_{\mathrm{sh}}$ stand to benefit the most from mitigation of eutrophication as phytoplankton concentrations may decrease with nutrient loading reductions. This will also diminish the proliferation of macroalgae, which compete with seagrass and have been implicated in seagrass loss.

\section{Conclusions}

Understanding the temporal and spatial variability of light attenuation is critical for establishing potential success of seagrass community restoration and estimating the recovery of estuaries from eutrophication. We quantified light attenuation and dissolved and particulate light inhibitors with hightemporal resolution in three seagrass meadows of Barnegat Bay, New Jersey. We found a strong south-to-north gradient in light attenuation that is mainly forced by turbidity and sediment supply in the southern part of the bay. Regular windwave resuspension, infrequent storms, and runoff events all contributed to sizable temporal fluctuations in light attenuation at all shoal sites. Individual storms were capable of doubling light attenuation over periods longer than $1 \mathrm{~d}$ through wind-wave resuspension and increased river flow. Changing patterns of storm intensity and frequency may have a long-term effect on the light climate in back-barrier estuaries. Wave heights and turbidity over the shoals appeared to be the result of wind rather than vessel traffic. Light attenuation was lowest in the most trafficked areas of the estuary, indicating that direct impact of vessel wakes on light attenuation is minimal. Spatial and temporal data of this type are necessary for modeling the response of seagrass communities to sea-level rise, storms, and nutrient loading. Numerical models of hydrodynamics, sediment transport, and ecology can be constrained with these measurements and used to guide restoration and habitat characterization.
Author contributions. N. K. Ganju designed the time-series experiment and analyzed the time-series data, A. L. Aretxabaleta implemented the light model, and J. L. Miselis designed the sediment sampling program and analyzed the surficial sediment data. All authors contributed to the drafting of the manuscript.

Acknowledgements. Funding was provided by the New Jersey Department of Environmental Protection and the U.S. Geological Survey Coastal and Marine Geology Program. The authors thank the Rutgers University Marine Field Station for their support, especially Tom Malatesta, Roland Hagan, Rose Petrecca, and Ken Able. Field and analytical support was provided by Sandy Baldwin, Jon Borden, Zafer Defne, Patrick Dickhudt, and Kate McMullen. Charles Gallegos graciously provided light model code, and Emmanuel Boss offered helpful suggestions for data analysis. Jessie Lacy and John Pohlman provided helpful comments on the manuscript. Any use of trade, firm, or product names is for descriptive purposes only and does not imply endorsement by the U.S. Government.

Edited by: B. A. Bergamaschi

\section{References}

Biber, P. D., Gallegos, C. L., and Kenworthy, W. J.: Calibration of a bio-optical model in the North River, NC: A tool to evaluate water quality impact on seagrasses, Estuar. Coast., 31, 177-191, 2008.

Booij, N., Ris, R. C., and Holthuijsen, L. H.: A third-generation wave model for coastal regions, 1 . Model description and validation, J. Geophys. Res., 104, 7667-7681, 1999.

Boss, E., Twardowski, M. S., and Herring, S.: Shape of the particulate beam attenuation spectrum and its inversion to obtain the shape of the particulate size distribution, Appl. Opt., 41, 48854893, 2001

Bowers, D. G. and Binding, C. E.: The optical properties of mineral suspended particles: A review and synthesis, Estuar. Coast. Shelf S., 67, 219-230, 2006.

Bricaud, A., Morel, A., and Prieur, L.: Absorption by dissolved organic matter of the sea (yellow substance) in the UV and visible domains, Limnol. Oceanogr., 26, 43-53, 1981.

Bricaud, A., Babin, M., Morel, A., and Claustre, H.: Variability in the chlorophyll-specific absorption coefficients of natural phytoplankton: Analysis and parameterization, J. Geophys. Res., 100, 13321-13332, 1995.

Brodtkorb, P. A., Johannesson, P., Lindgren, G., Rychlik, I., Ryden, J., and Sjo, E.: WAFO - a Matlab toolbox for analysis of random waves and loads, Proceedings of the 10th International Offshore Polar Engineering Conference, Seattle, WA, III, 343-350, 2000.

Burkholder, J. M., Tomasko, D. A., and Touchette, B. W.: Seagrasses and eutrophication, J. Exp. Mar. Biol. Ecol., 350, 46-72, 2007.

Chant, R. J.: Tidal and subtidal motion in a shallow bar-built multiple inlet/bay system, J. Coastal Res., 32, 102-114, 2001.

Chen, R. F., Gardner, B., Huang, W., and Peri, F.: Chromophoric Dissolved Organic Matter (CDOM) in United States Estuaries, Proceedings of the 10th IEBS, Xiamen, China, May 18-22, 2008. 
Christian, D. and Sheng, Y. P.: Relative influence of various water quality parameters on light attenuation in Indian River Lagoon, Estuar. Coast. Shelf S., 57, 961-971, 2003.

Collias, E. E., Rona, M. R., McManus, D. A., and Creager, J. S.: Machine processing of geological data, University of Washington Technical Report, no. 87, 119 pp., 1963.

Defne, Z. and Ganju, N. K.: Quantifying the residence time and flushing characteristics of a shallow, back-barrier estuary: application of hydrodynamic and particle tracking models, Estuar. Coast., 1-16, 2014.

Donnelly, J. P., Roll, S., Wengren, M., Butler, J., Lederer, R., and Webb, T.: Sedimentary evidence of intense hurricane strikes from New Jersey, Geology, 29, 615-618, 2001.

Downing, B. D., Boss, E., Bergamaschi, B. A., Fleck, J. A., Lionberger, M. A., Ganju, N. K., Schoellhamer, D. H., and Fujii, R.: Quantifying fluxes and characterizing compositional changes of dissolved organic matter in aquatic systems in situ using combined acoustic and optical measurements, Limnol. Oceanogr.Meth., 7, 119-131, 2009.

Downing, B. D., Pellerin, B. A., Bergamaschi, B. A., Saraceno, J. F., and Kraus, T. E.: Seeing the light: The effects of particles, dissolved materials, and temperature on in situ measurements of DOM fluorescence in rivers and streams, Limnol. Oceanogr.Meth., 7, 767-775, 2012.

Environmental Protection Agency: National Estuary Program Coastal Condition Report, Chapter 3: Northeast National Estuary Program Coastal Condition, Barnegat Bay National Estuary Program, available at: http://water.epa.gov/type/oceb/nep/upload/ 2007_05_09_oceans_nepccr_pdf_large_section2.pdf (last access: 10 December 2014), 2007.

Folk, R. L.: Petrology of Sedimentary Rocks, Hemphill Publishing Co., Austin, Texas, 182 pp., 1974.

Fonseca, M. S. and Cahalan, J. A.: A preliminary evaluation of wave attenuation by four species of seagrass, Estuar. Coast. Shelf S., 35, 565-576, 1992.

Gallegos, C. L., Werdell, P. J., and McClain, C. R.: Long-term changes in light scattering in Chesapeake Bay inferred from Secchi depth, light attenuation, and remote sensing measurements, J. Geophys. Res. 116, C00H08, doi:10.1029/2011JC007160, 2011.

Ganju, N. K., Schoellhamer, D. H., Warner, J. C., Barad, M. F., and Schladow, S. G.: Tidal oscillation of sediment between a river and a bay: a conceptual model, Estuar. Coast. Shelf S., 60, 8190, 2004.

Ganju, N. K., Nidzieko, N. J., and Kirwan, M. L.: Inferring tidal wetland stability from channel sediment fluxes: Observations and a conceptual model, J. Geophys. Res.-Earth, 118, 2045-2058, 2013.

Glibert, P. M., Wazniak, C. E., Hall, M. R., and Sturgis, B.: Seasonal and interannual trends in nitrogen and brown tide in Maryland's coastal bays, Ecol. Appl., 17, 79-87, 2007.

Howarth, R. W. and Marino, R.: Nitrogen as the limiting nutrient for eutrophication in coastal marine ecosystems: evolving views over three decades, Limnol. Oceanogr., 51, 364-376, 2006.

Kennish, M. J., Bricker, S. B., Dennison, W. C., Glibert, P. M., Livingston, R. J., Moore, K. A., Noble, R. T., Paerl, H. W., Ramstack, J. M., Seitzinger, S., Tomasko, D .A., and Valiela, I.: Barnegat Bay - Little Egg Harbor Estuary: case study of a highly eutrophic coastal bay system, Ecol. Appl. 17, 3-16, 2007.
Kennish, M. J., Fertig, B. M., and Sakowicz, G. P.: Benthic macroalgal blooms as an indicator of system eutrophy in the Barnegat Bay - Little Egg Harbor estuary, Bulletin of the New Jersey Academy of Science, 56, 1-5, 2011.

Kennish, M. J., Fertig, B. M., and Sakowicz, G. P.: In situ Surveys of Seagrass Habitat in the Northern Segment of the Barnegat Bay-Little Egg Harbor Estuary: Eutrophication Assessment, available at: http://bbp.ocean.edu/Reports/ 2011Northernseagrasssurvey.pdf (last access: 10 December 2014), 2013.

Kirk, J. T. O.: Light and photosynthesis in aquatic ecosystems, Cambridge University Press, 509 pp., 1994.

Lacy, J. R. and Wyllie-Echeverria, S.: The influence of current speed and vegetation density on flow structure in two macrotidal eelgrass canopies, Limnol. Oceanogr.: Fluids and Environments, 1, 38-55, 2011.

Lathrop, R. G. and Haag, S. M.: Assessment of seagrass status in the Barnegat Bay-Little Egg Harbor Estuary system: 2003 and 2009, Center for Remote Sensing and Spatial Analysis report, 56 pp., 2011.

Lathrop, R. G., Montesano, P., and Haag, S.: A multi-scale segmentation approach to mapping seagrass habitats using airborne digital camera imagery, Photogramm. Eng. Rem. S., 72, 665-675, 2006.

Lawrenz, E. and Richardson, T. L.: How does the species used for calibration affect chlorophyll a measurements by in situ fluorometry?, Estuar. Coast., 34, 872-883, 2011.

Lawson, S. E., Wiberg, P. L., McGlathery, K. J., and Fugate, D. C.: Wind-driven sediment suspension controls light availability in a shallow coastal lagoon, Estuar. Coast., 30, 102-112, 2007.

Lee, Z.-P., Du, K.-P., and Arnone, R.: A model for the diffuse attenuation coefficient of downwelling irradiance, J. Geophys. Res., 110, C02016, doi:10.1029/2004JC002275, 2005.

Loisel, H., Meìriaux, X., Berthon, J.-F., and Poteau, A.: Investigation of the optical backscattering to scattering ratio of marine particles in relation to their biogeochemical composition in the eastern English Channel and southern North Sea, Limnol. Oceanogr., 52, 739-752, doi:10.4319/lo.2007.52.2.0739, 2007.

Madsen, O.S.: Spectral wave - current bottom boundary layer flows, Proceedings of the 24th International Conference Coastal Engineering Research Council, Kobe, Japan, 384-398, 1994.

Mariotti, G. and Fagherazzi, S.: Critical width of tidal flats triggers marsh collapse in the absence of sea-level rise, P. Natl. Acad. Sci., 110, 5353-5356, 2013.

Maxwell, K. and Johnson, G. N.: Chlorophyll fluorescence - a practical guide, J. Exp. Bot., 51, 659-668, 2000.

McGlathery, K. J., Anderson, I. C., and Tyler, A. C.: Magnitude and variability of benthic and pelagic metabolism in a temperate coastal lagoon, Mar. Ecol. Prog. Ser., 216, 1-15, 2001.

Meyercordt, J., Gerbersdorf, S., and Meyer-Reil, L. A.: Significance of pelagic and benthic primary production in two shallow coastal lagoons of different degrees of eutrophication in the southern Baltic Sea, Aquat. Microb. Ecol., 20, 273-284, 1999.

Mobley, C. D. and Stramski, D.: Effects of microbial particles on oceanic optics: Methodology for radiative transfer modeling and example simulations, Limnol. Oceanogr., 42, 550-560, 1997.

New Jersey Department of Environmental Protection: Environmentally Sensitive Areas Guidance Document, available at: http://www.nj.gov/dep/rpp/brp/dp/downloads/DPCC_ 
Environmentally_Sensitive_Areas_Guidance.pdf (last access: 10 December 2014), 2012.

Oertel, G. F.: The barrier island system, Mar. Geol., 63, 1-18, 1985. Oestreich, W. K., Ganju, N. K., Pohlman, J. W., and Suttles, S. E.: Colored dissolved organic matter in shallow estuaries: the effects of source and transport on light attenuation and measurement, American Geophysical Union Fall Meeting Abstracts, 2014.

Phlips, E. J., Lynch, T. C., and Badylak, S.: Chlorophyll a, tripton, color, and light availability in Florida Bay, USA, Mar. Ecol. Prog. Ser., 127, 223-234, 1995.

Phlips, E. J., Badylak, S., and Grosskopf, T.: Factors affecting the abundance of phytoplankton in a restricted subtropical lagoon, the Indian River Lagoon, Florida, USA, Estuar. Coast. Shelf S., 55, 385-402, 2002.

Poppe, L. J., Eliason, A. H., and Hastings, M. E.: A Visual Basic program to generate sediment grain-size statistics and to extrapolate particle distributions, Comput. Geosci., 30, 791-795, 2004.

Preisendorfer, R. W.: Hydrologic Optics, 2, Foundations, Honolulu: US Dept. of Commerce, National Oceanic and Atmospheric Administration, Environmental Research Laboratories, Pacific Marine Environmental Laboratory, 410 pp., 1976.

Ren, L.: Baseline characterization of phytoplankton and harmful algal blooms in Barnegat Bay-Little Egg Harbor, New Jersey (year one), Final report to the New Jersey Department of Protection Science and Research, 100 pp., 2013.
Schoellhamer, D. H.: Variability of suspended-sediment concentration at tidal to annual time scales in San Francisco Bay, USA, Cont. Shelf Res., 22, 1857-1866, 2002.

Snyder, W. A., Arnone, R. A., Davis, C. O., Goode, W., Gould, R. W., Ladner, S., Lamela, G., Rhea, W. J., Stavn, R., Sydor, M. and Weidemann, A.: Optical scattering and backscattering by organic and inorganic particulates in U.S. coastal waters, Appl. Opt., 47, 666-677, doi:10.1364/AO.47.000666, 2008.

Spencer, R. G., Aiken, G. R., Dornblaser, M. M., Butler, K. D., Holmes, R. M., Fiske, G., Mann, P.J., and Stubbins, A.: Chromophoric dissolved organic matter export from US rivers, Geophys. Res. Lett., 40, 1575-1579, 2013.

U.S. Army Corps of Engineers: Shore Protection Manual, 1 and 2, U.S. Army Corps of Engineers, Coastal Engineering Research Center, 1984.

Valentine, P. C., Blackwood, D. B., and Parolski, K. F.: Seabed Observation and Sampling System: US Geological Survey Fact Sheet FS-142-00, 2 pp., 2000.

Ziegler, S. and Benner, R.: Ecosystem metabolism in a subtropical seagrass-dominated lagoon, Mar. Ecol. Prog. Ser., 173, 1-12, 1998. 